\title{
Preparation of functionalised bicycles by means of vinyl ketene- cyclohexadienone electrocyclisations: an entry into terpenoid precursors
}

\author{
Ahmad Khodabocus \\ Department of Chemistry, University of Mauritius, Réduit, Mauritius \\ E-mail: ahmadk@condor.uom.ac.mu
}

\begin{abstract}
Cyclohexene derivatives $\mathbf{1 2}$ and $\mathbf{1 4}$ having an oxygen-functional group at C-(4) were found to undergo smooth vinylketene-cyclohexedienone cyclisations to furnish the highly functionalised bicyclic compounds 13, 15 and 16 in good chemical yields.
\end{abstract}

Key words: Vinylketene-cyclohexadienone, electrocyclisation

\section{Introduction}

Previous work ${ }^{1-3}$ has demonstrated not only synthetic value of vinylketene-cyclohexadienone cyclisations in the preparation of complex molecules but also the interesting stereoselection observed therein. In a previous communication ${ }^{2}$, we disclosed the stereochemical features of some divinylketene-cyclohexadienone cyclisations. Herein the full details of the preparation of bicyclic compounds reported above that can potentially be elaborated into precursors for terpenoids such as forskolin 1 will be described.

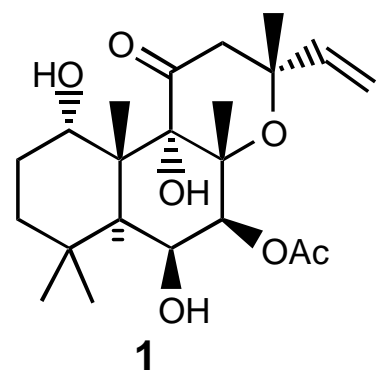

The observation ${ }^{4}$ that an oxygen functionality at C-8 of bicycle 2 can make the system rather unstable due to a potential retro-Prins type reaction driven by aromatisation of the dienone 
(Scheme 1) system prompted the search for a more stable molecule with a view to elaboration into forskolin precursors.

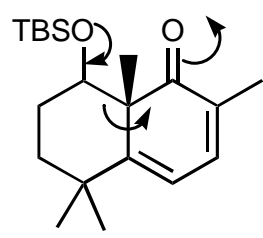

2

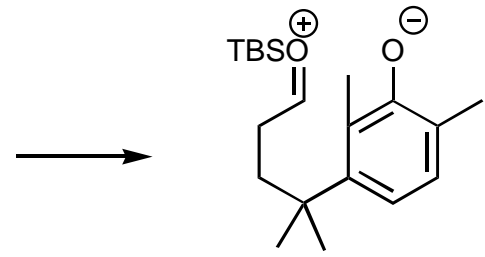

\section{Scheme 1}

The diketone $\mathbf{3}$ was identified as a possible solution to the problem, as the C-7 keto group could be transposed to $\mathrm{C}-8$ by a sequence involving reduction, dehydration in the correct regiochemical sense followed by epoxidation and reduction at a suitable juncture to give a system having the oxidation pattern of forskolin (Scheme 2). Furthermore, the ketone could also lend itself to further elaboration at its $\alpha$-carbon atoms by standard chemistry.
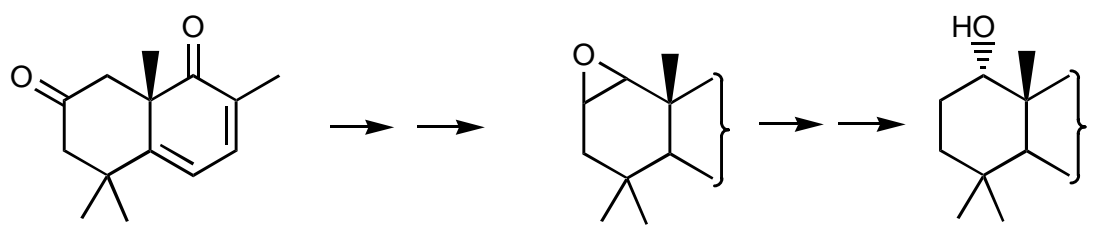

3

\section{Scheme 2}

Simple disconnection of $\mathbf{3}$ unveiled the readily available ketone 5 (Scheme 3). However, instead of trying the scheme with the acetylene 4 , which is not commercially available, the readily accessible simpler analogue 6 (see Scheme 4) was used.<smiles>C=CC1=CC=C2C(C)(C)CC(=O)C[C@@]2(C)C1=O</smiles>

3<smiles>C=CC(=O)C(C)/C=C\C1=C(C)CC(=O)CC1(C)C</smiles><smiles>CC1=CC(=O)CC(C)(C)C12C=CC(C)C(=O)O2</smiles><smiles>C=CC=CC1(O)C(C)=CC(=O)CC1(C)C#CC(C)CO</smiles><smiles>C=CC=CC1(O)C(C)=CC(=O)CC1(C)C#CC(C)CO</smiles><smiles>C=C</smiles>

\section{Scheme 3}

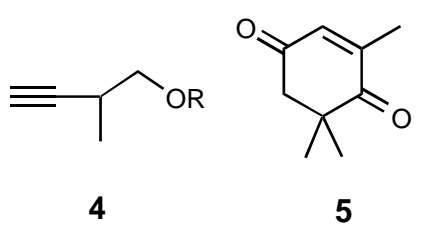




\section{Results and Discussion}

Diketone 5 was selectively protected using ethylene glycol in refluxing benzene in the presence of cat. $p$-TSA to give ketone 7 in $80 \%$ after distillation. ${ }^{5}$ Coupling with the lithium acetylide of tetrahydropyrannylated 3-butyn-1-ol $\mathbf{6}$ gave the desired propargylic alcohol $\mathbf{8}$ in high yield. The ${ }^{1} \mathrm{H}$ NMR displayed an olefinic singlet at $5.25 \mathrm{ppm}$ and two methylene signals at $2.55 \mathrm{ppm}$ and $3.55 \mathrm{ppm}$ attributable to the methylene groups of the side chain. The dioxolane and tetrahydropyran groups were then removed straightforwardly by exposure to cat. pyridinium tosylate in refluxing ethanol. This afforded the diol $\mathbf{9}$ in $89 \%$ overall yield from $\mathbf{6}$ after purification by chromatography. The ${ }^{1} \mathrm{H}$ NMR of 9 displayed an olefinic singlet at $5.85 \mathrm{ppm}$ and two side chain triplets at $2.50 \mathrm{ppm}$ and $3.75 \mathrm{ppm}$ attributable to the propargylic and carbinolic methylene groups respectively. It is worth noting that the dioxolane could be selectively removed by brief exposure to cat. $p$-TSA in aqueous acetone. The diol 9 was partially hydrogenated in the presence of Lindlar's catalyst to afford the desired cis-alkene $\mathbf{1 0}$ in $89 \%$ yield after purification by chromatography. The olefinic protons appeared as a multiplet at $5.65 \mathrm{ppm}$ while the allylic and homoallylic protons resonated at $2.65 \mathrm{ppm}$ and $3.75 \mathrm{ppm}$ as multiplets respectively. Alkene 10 was subsequently oxidized into spirolactone $\mathbf{1 1}$ by exposure to Jones' reagent; the product was obtained in $45 \%$ yield as white crystals $\left(\mathrm{mpt}: 86-88^{\circ} \mathrm{C}\right.$ ) after purification by chromatography. The ${ }^{1} \mathrm{H}$ NMR spectrum displayed the olefinic peaks of the lactone moiety at $6.04 \mathrm{pm}$ and $5.85 \mathrm{ppm}$ as a doublet of triplets attributable to the $\beta-\mathrm{H}$ and $\gamma-\mathrm{H}$ of the lactone, respectively. The lactone methylene appeared as a triplet at $3.15 \mathrm{ppm}$ while the remaining olefinic proton exhibited a fine doublet at $5.90 \mathrm{ppm}$ due to allylic coupling. Subsequently it was found that the spirolactone could be obtained in $78 \%$ yield by reaction of 10 with PCC at ambient temperature. Spirolactone 11 underwent smooth reductive fragmentation using freshly prepared samarium(II) iodide ${ }^{6}$ to give the acid $\mathbf{1 2}$ in nearly quantitative yield. The ${ }^{1} \mathrm{H}$ NMR of $\mathbf{1 2}$ showed the two side chain olefinic protons as a doublet of triplets at $5.85 \mathrm{ppm}$ and a fine doublet of doublets at $6.10 \mathrm{ppm}$, the latter being due to the proton further away from the acid group.

With the acid in hand, generation of the vinyl-ketene was attempted using the standard protocol of conversion of the acid to the corresponding acid chloride by reaction with oxalyl chloride followed by dehydrohalogenation with triethylamine. Unfortunately under these conditions, only decomposition was observed. Reaction in refluxing dichloromethane with the milder reagent 2-chloro- $N$-methylpyridinium iodide (2-CNMPI) in the presence of triethylamine gave the expected bicycle 13 in $60 \%$ as yellow needles (mpt: $86-87^{\circ} \mathrm{C}$ ) after purification by chromatography. The ${ }^{1} \mathrm{H}$ NMR spectrum of $\mathbf{1 3}$ displayed the three olefinic protons of the dienone moiety as a doublet at $5.98 \mathrm{ppm}$, a doublet of doublets at $7.05 \mathrm{ppm}$ and another doublet at $6.30 \mathrm{ppm}$ attributable to the $\alpha, \beta$ and $\gamma$-protons respectively. The C-8 methylene group appeared as an $\mathrm{AB}$ quartet at $2.75 \mathrm{ppm}$ while that at C-6 resonated as a triplet at $2.40 \mathrm{ppm}$. Dienone $\mathbf{1 3}$ could also be obtained in $43 \%$ yield by exposure of acid $\mathbf{1 2}$ to acetic anhydride. 
<smiles>CC1=CC(=O)CC(C)(C)C1=O</smiles>
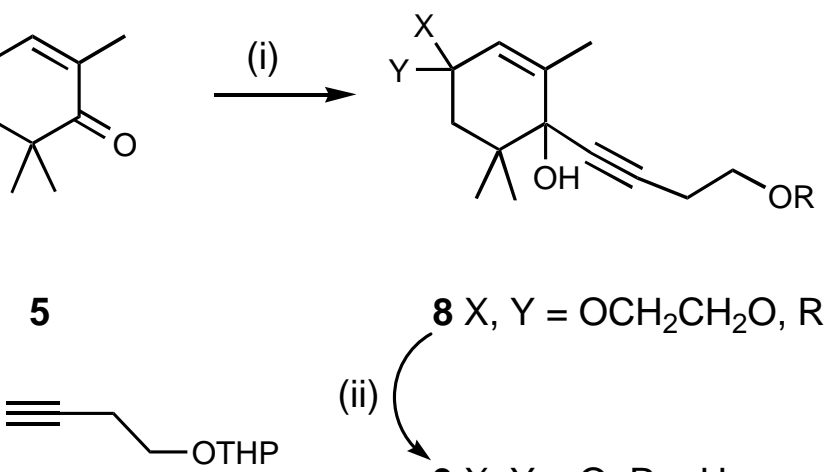

6

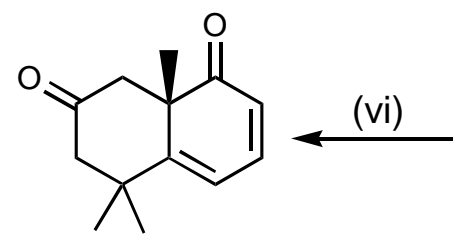

13 (ii)

$8 \times, \mathrm{Y}=\mathrm{OCH}_{2} \mathrm{CH}_{2} \mathrm{O}, \mathrm{R}=\mathrm{THP}$<smiles></smiles>

12

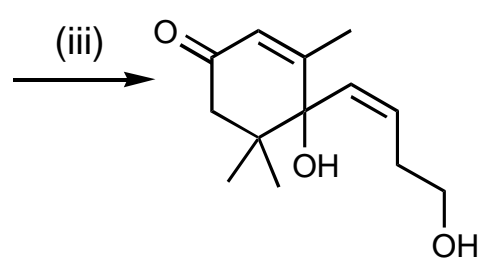

10

(i) (a) $\left(\mathrm{CH}_{2} \mathrm{OH}\right)_{2}, \mathrm{pTSA}, \mathrm{C}_{6} \mathrm{H}_{6}$, reflux; (b) n-BuLi, 6, THF, $-78^{\circ} \mathrm{C}$, then 7; (ii) PyHOTs, EtOH, reflux; (iii) $\mathrm{H}_{2}$, Lindlar's cat., EtOAc, RT; (iv) PCC or Jones' reagent; (v) $\mathrm{SmI}_{2}$, THF, RT; (vi) 2-CNMPI, Et3N, DCM, reflux

\section{Scheme 4}

Having obtained a viable route to the desired bicycle, the synthesis of other derivatives was investigated, especially those that would be amenable to elimination reactions. With this in mind, ketoacid 12 was straightforwardly reduced, using sodium borohydride in methanol at $-78^{\circ} \mathrm{C}$, to give the expected hydroxyacid $\mathbf{1 4}$ in nearly quantitative yield. This was then exposed to an excess of acetic anhydride in pyridine containing a catalytic amount of DMAP, whereupon the bicycle 15 was obtained as a mixture of diastereomers in $68 \%$ overall yield from the spirolactone 11 after silica gel chromatography. Capillary GC analysis revealed a 7:3 product ratio of isomers. The major product 15a exhibited three olefinic signals at $5.89 \mathrm{ppm}$ (doublet), $7.00 \mathrm{ppm}$ (doublet of doublets) and $6.22 \mathrm{ppm}$ (doublet). The acetoxy methine appeared as a multiplet at $5.13 \mathrm{ppm}$. The C-8 protons appeared as a pair of doublets of doublet at $1.69 \mathrm{ppm}$ and $2.21 \mathrm{ppm}$. The minor isomer $\mathbf{1 5 b}$ had similar signals as the major one except for the C-7 methine proton, which appeared as a highly symmetrical triplet of triplets, indicating a symmetry element between the C-6 and C-8 atoms. Furthermore there was a significant NOE between the C-7-proton and the angular methyl group. Ring opening of cyclohexadienones to the corresponding dienylketenes is known to occur photochemically. ${ }^{7}$ In the present study it was noted that upon thermolysis of the dienones 15 in refluxing o-dichlorobenzene for 10 hours, a different product mixture was isolated and was found to contain $\mathbf{1 5 a}$ and $\mathbf{1 5 b}$ in the ratio of 1:3. This rearrangement 
presumably occurs by a mechanism similar to the Barton-Quinkert reaction, involving a formal cycloreversion of the dienone system followed by ring closure to give the more stable isomer as the major product.

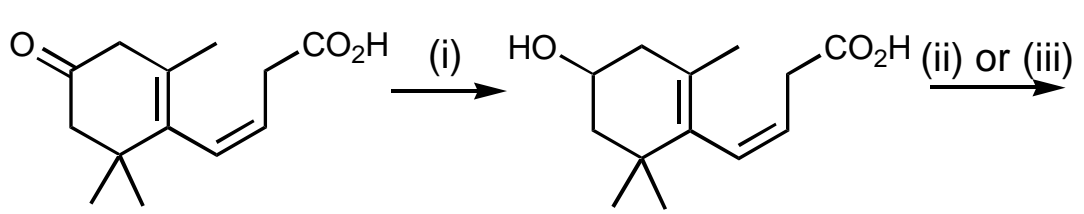

12
14

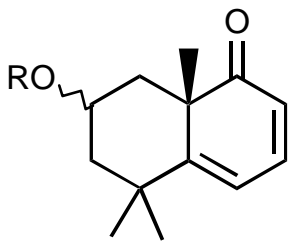

$15 \mathrm{a} R=\alpha-\mathrm{OAC}$

15b $\mathrm{R}=\beta-\mathrm{OAC}$

$16 \mathrm{R}=\mathrm{OMs}$

(i) $\mathrm{NaBH}_{4},-78^{\circ} \mathrm{C}, \mathrm{MeOH}$; (ii) $\mathrm{Ac}_{2} \mathrm{O}, \mathrm{Py}, \mathrm{DMAP}, 0^{\circ} \mathrm{C}->\mathrm{RT}$ (iii) $\mathrm{MsCl}, \mathrm{Py}, 0^{\circ} \mathrm{C}->\mathrm{RT}$

\section{Scheme 5}

Having secured a method to prepare the acetates 15, we turned our attention to the preparation of derivatives more amenable to elimination reactions. To this end hydroxy acid 14 was exposed to thionyl chloride in the presence of pyridine. The reasoning behind the approach was that under these conditions, it was hoped that the alcohol would dehydrate toward the existing double bond prior to generation of the ketene intermediate thereby giving the desired product. Unfortunately, the use of thionyl chloride and pyridine resulted in decomposition. Similarly, exposure to triflic anhydride in pyridine at $0^{\circ} \mathrm{C}$ gave a very complex mixture. Finally, reaction with mesyl chloride in pyridine gave a mixture of mesylates $\mathbf{1 6}$ in $50 \%$ yield from spirolactone 11. The reaction occurs presumably through the formation of a mixed anhydride of the carboxylic acid with mesyl chloride and subsequent elimination to give the vinylketene intermediate. The ${ }^{1} \mathrm{H}$ NMR spectrum showed the olefinic signals associated with the dienone moiety at 5.80, 6.95 and $6.15 \mathrm{ppm}$ attributable to the protons in the $\alpha, \beta$ and $\gamma$-positions respectively with respect to the carbonyl group. The mesylate methine proton appeared as a broad multiplet centred at $5.00 \mathrm{ppm}$. Elimination of the mesylate proved troublesome: thus treatment with DBU in refluxing chloroform gave a very low yield of regioisomeric alkenes 17. Potassium t-butoxide in refluxing THF also gave similar results, except that the elimination was faster (Scheme 6). 


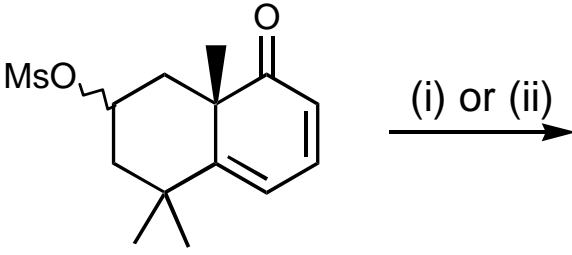

16<smiles>CC1=CC=CC(=O)C12C=CC=CC2(C)C</smiles>

17

(i) $\mathrm{DBU}, \mathrm{CHCl}_{3}$, reflux; (ii) $\mathrm{KOBu}^{\mathrm{t}}$, THF, reflux

\section{Scheme 6}

Whilst the methodology described in this paper appears to be reasonably versatile in so far as it allows easy access to functionalised bicyclic systems, there is still the need for an efficient elimination reaction. For future work, the possibility of performing a selenium-based elimination of hydroxy-acid $\mathbf{1 4}$ prior to cyclisation will be examined. Furthermore it seems that there is good stereoselection in the electrocyclisation reaction only when the substituent on the cyclohexene is adjacent to the site of cyclisation. ${ }^{2}$

\section{Experimental Section}

General Procedures. Infrared spectra were run as thin films. The NMR spectra were run at 300 $\mathrm{MHz}$ for ${ }^{1} \mathrm{H}$ NMR in $\mathrm{CDCl}_{3}$ solution using tetramethylsilane (TMS) as internal standard. Mass spectra and high-resolution mass spectra (HRMS) were measured using the electron impact (EI) technique. Infra red spectra were recorded as thin films. Chromatography refers to the flash column technique over Merck Kiesel gel 60H (230-400 mesh) and thin layer chromatography was carried out using plates precoated with Merck silica $60 \mathrm{~F}_{254}$. Ether and petrol (fraction boiling between $40^{\circ}$ and $60^{\circ} \mathrm{C}$ ) were distilled prior to use. Tetrahydrofuran was dried by refluxing over sodium and benzophenone under nitrogen and then distillation. Dichloromethane, acetonitrile, pyridine and triethylamine were dried by refluxing over calcium hydride and were then distilled.

Preparation of 1,4-dioxaspiro[4.5]-7,9,9-trimethyl-8-oxo-6-decene (7) ${ }^{5}$. 2,6,6-Trimethyl-2cyclohexen-1,4-dione 5 (14.76 g; $9.71 \mathrm{mmol})$, ethylene glycol (9.0 g; $14.52 \mathrm{mmol})$ and PTSA $(0.40 \mathrm{~g}$; cat) were dissolved in benzene $(110 \mathrm{ml})$ and the mixture was refluxed for about 18 hours using a Dean-Stark water separator (or until no more water appeared to be produced). The mixture was then taken up in ether $(150 \mathrm{ml})$; washed successively with water $(25 \mathrm{ml})$; sodium bicarbonate solution $(25 \mathrm{ml})$; brine $(1 \times 25 \mathrm{ml})$ and finally dried $\left(\mathrm{Na}_{2} \mathrm{SO}_{4}\right)$. The solution was concentrated under reduced pressure to afford the crude product as a brownish oil, which upon vacuum distillation, gave the product 7 as a yellowish oil $\left(15.4 \mathrm{~g} ; 81 \%\right.$; bpt: $\left.94-105^{\circ} \mathrm{C} / 2 \mathrm{mmHg}\right)$. $v_{\max } 1675 \mathrm{~cm}^{-1} ; \delta_{\mathrm{H}}\left(\mathrm{CDCl}_{3}\right) 6.20(1 \mathrm{H}, \mathrm{bs}) ; 3.90(4 \mathrm{H}, \mathrm{s}) ; 1.95(2 \mathrm{H}, \mathrm{s}) ; 1.75(3 \mathrm{H}, \mathrm{bs}) ; 1.25(6 \mathrm{H}, \mathrm{s})$. 
Preparation of 4-[1,4-dioxaspiro[4.5]-8-hydroxy-7,9,9-trimethyl-6-decenyl]-1-tetrahydropyranyloxy3-butyne (8). A solution of 1-tetrahydropyranyloxy-3-butyne 6 (3.396 g; $22.05 \mathrm{mmol}$; $1.5 \mathrm{~mol} \mathrm{eq})$ in dry THF $(30 \mathrm{ml})$ in a flame-dried flask was treated with a $1.6 \mathrm{M}$ solution of n-butyllithium in hexanes $(12.0 \mathrm{ml}, 19.02 \mathrm{mmol} ; 1.33 \mathrm{~mol} \mathrm{eq})$ at $-78^{\circ} \mathrm{C}$ under nitrogen. The solution was stirred for 30 minutes at $-78^{\circ} \mathrm{C}$, warmed up to $0^{\circ} \mathrm{C}$ over 15 minutes and then cooled down again to $78^{\circ} \mathrm{C}$. A solution of ketone $7(2.788 \mathrm{~g} ; 14.22 ; 1.0 \mathrm{~mol} \mathrm{eq})$ in dry THF $(5 \mathrm{ml})$ was slowly added to the solution of the lithium acetylide. The yellowish solution was stirred at $-78^{\circ} \mathrm{C}$ for 2 hours after which it was allowed to slowly warm up to room temperature (ca. 1 hour). The reaction was quenched by slow addition of saturated ammonium chloride solution $(25 \mathrm{ml})$. The layers were partitioned and separated in the usual way and the aqueous phase was extracted with ether $(2 \mathrm{x}$ $25 \mathrm{ml})$. The combined organics were washed with brine $(1 \mathrm{x} 25 \mathrm{ml})$ and dried $\left(\mathrm{Na}_{2} \mathrm{SO}_{4}\right)$. Evaporation of volatiles provided the crude product as yellowish oil which was routinely carried forward as such. An analytical sample was obtained by chromatography (1:2 petrol/ether), which gave the pure product 8 as an almost colorless oil. $v_{\max } 3450 ; 2244 \mathrm{~cm}^{-1} . \delta_{\mathrm{H}}\left(\mathrm{CDCl}_{3}\right), 5.25(1 \mathrm{H}$, s); $4.60(1 \mathrm{H}, \mathrm{bs}) ; 3.85(4 \mathrm{H}, \mathrm{s}) ; 3.55(4 \mathrm{H}, \mathrm{bm}) ; 2.50(3 \mathrm{H}, \mathrm{t}, \mathrm{J}=7.0 \mathrm{~Hz}) ; 1.85(3 \mathrm{H}$, fine d; J=1.5 Hz); $1.15(3 \mathrm{H}, \mathrm{s}) ; 1.05(3 \mathrm{H}, \mathrm{s}) ; 1.65-1.00(7 \mathrm{H}, \mathrm{bm}) . \mathrm{m} / \mathrm{e}$ found $\left(\mathrm{M}^{+}+1\right): 351.2175 ; \mathrm{C}_{20} \mathrm{H}_{30} \mathrm{O}_{5}+1$ requires 351.2171 .

Preparation of 4-Hydroxy-4-[4-hydroxy-1-butynyl]-3,5,5-trimethyl-2-cyclohex-1-one (9). The crude product 8 from the previous experiment (ca. $6.30 \mathrm{~g}$ ) was dissolved in $95 \%$ ethanol (50 $\mathrm{ml}$ ) and the solution was charged with a small quantity of PPTS (ca. $200 \mathrm{mg}$ ). The solution was refluxed for 2 hours under nitrogen after which the solvent was evaporated on a rotary evaporator. The crude product was purified by chromatography $(30 \%$ ether/petrol $\rightarrow$ neat ether) to give the desired product 9 as yellowish oil (2.83 g; 89\% over 2 steps). $v_{\max }: 3350,1657,1640$ $\mathrm{cm}^{-1} . \delta_{\mathrm{H}}\left(\mathrm{CDCl}_{3}\right) 5.85(1 \mathrm{H}, \mathrm{s}) ; 3.75(2 \mathrm{H}, \mathrm{t} ; \mathrm{J}=6.0 \mathrm{~Hz}) ; 2.50(2 \mathrm{H}, \mathrm{t}, \mathrm{J}=6.0 \mathrm{~Hz}) ; 2.45(2 \mathrm{H}, \mathrm{q} ; 16.0$ $\mathrm{Hz}) ; 2.10(3 \mathrm{H}$, fine $\mathrm{d} ; \mathrm{J}=1.5 \mathrm{~Hz}) ; 1.20(3 \mathrm{H}, \mathrm{s}) ; 1.10(3 \mathrm{H}, \mathrm{s}) . \mathrm{m} / \mathrm{e}$ found $(\mathrm{M}+1)^{+} 223.1337$; $\mathrm{C}_{13} \mathrm{H}_{18} \mathrm{O}_{3}+1$ requires 223.1334

\section{Preparation of 4-Hydroxy-4-[4-hydroxy-(z)-1-butenyl]-3,5,5-trimethyl-2-cyclohex-1-one} (10). Acetylene diol $9(140 \mathrm{mg} ; 0.631 \mathrm{mmol})$ was dissolved in ethyl acetate $(10 \mathrm{ml})$ and the solution was charged with Lindlar's catalyst $(20 \mathrm{mg})$. The suspension was vigorously stirred under an atmosphere of hydrogen. TLC (neat ether) showed that the reaction was complete after 1 hour. The suspension was filtered through a pad of Celite and the filtrate was concentrated to afford the crude product. Purification by chromatography (10:1 ether/petrol) furnished the title compound 10 as an almost colorless oil $(128 \mathrm{mg} ; 89 \%) . v_{\max } 3352 ; 1654 \mathrm{~cm}^{-1} . \delta_{\mathrm{H}}\left(\mathrm{CDCl}_{3}\right) 5.80$ $(1 \mathrm{H}, \mathrm{s}) ; 5.65(2 \mathrm{H}, \mathrm{m}) ; 3.75(2 \mathrm{H}, \mathrm{m}) ; 2.65(2 \mathrm{H}, \mathrm{m}) ; 2.35(2 \mathrm{H}, \mathrm{q} ; \mathrm{J}=17.0 \mathrm{~Hz}) ; 1.95(3 \mathrm{H}, \mathrm{s}) ; 1.05$ $(6 \mathrm{H}, \mathrm{s})$.

\section{Spirolactonisation of diol 10 using Jones' reagent}

A solution of diol $10(570 \mathrm{mg}, 2.545 \mathrm{mmol})$ in ether $(15 \mathrm{ml})$ was treated with freshly prepared Jones' reagent $(4.0 \mathrm{ml}, \mathrm{xs})$ at $0^{\circ} \mathrm{C}$ and the suspension was vigorously stirred. The reaction was found to be complete after about 3 hours. The suspension was treated with ether $(50 \mathrm{ml})$ and 
filtered through a pad of Celite; the filtrate was washed with water; sodium bicarbonate solution, brine and finally dried $\left(\mathrm{Na}_{2} \mathrm{SO}_{4}\right)$. Evaporation of the solvent afforded the crude product which, upon chromatography (neat ether) gave the product 11 as a white crystalline solid (254 mg; $45 \%)$. mpt, $86-8^{\circ} \mathrm{C} ; v_{\max } 1745 ; 1669 ; 1640 \mathrm{~cm}^{-1} . \delta_{\mathrm{H}}\left(\mathrm{CDCl}_{3}\right) 6.05(1 \mathrm{H}, \mathrm{dt} ; \mathrm{J}=10.0 \mathrm{~Hz}$ and $\mathrm{J}=3.5$ $\mathrm{Hz}) ; 5.90(1 \mathrm{H}$, fine d; J=1.0 Hz); $5.84(1 \mathrm{H}, \mathrm{dt} ; \mathrm{J}=10.0 \mathrm{~Hz}$ and $\mathrm{J}=2.0 \mathrm{~Hz}) ; 3.15(2 \mathrm{H}, \mathrm{t} ; \mathrm{J}=3.0 \mathrm{~Hz})$, $2.45(2 \mathrm{H}, \mathrm{s}) ; 1.90(3 \mathrm{H}, \mathrm{s}) ; 1.18(3 \mathrm{H}, \mathrm{s}) ; 1.05(3 \mathrm{H}, \mathrm{s})$. (Found C: 70.7; H: 7.3. Calc. for $\mathrm{C}_{13} \mathrm{H}_{16} \mathrm{O}_{3}$ : C, 70.9; H, 7.3)

\section{Spirolactonisation of diol 10 using PCC}

Diol $10(370 \mathrm{mg} ; 1.652 \mathrm{mmol})$ was dissolved in dry DCM $(10 \mathrm{ml})$ and the solution was successively treated with PCC (1.775 g; $8.236 \mathrm{mmol}, 5.0 \mathrm{~mol}$ eq) and powdered 3A sieves (2 spatula tips) and put under nitrogen. The suspension was stirred at ambient temperature for ca. 3 hours. More Celite was added, followed by ether $(40 \mathrm{ml})$. After trituration, the suspension was filtered through a pad of $\mathrm{SiO}_{2}$, which was washed with another portion of ether $(50 \mathrm{ml})$. The filtrate was concentrated and the crude product was chromatographed on silica (neat ether) to give desired product 11 as a white solid $(284 \mathrm{mg} ; 78 \%)$.

Preparation of 4-[2,6,6-trimethyl-4-oxocyclohex-1-enyl]-(z)-3-butenoic acid (12). Samarium powder $(887 \mathrm{mg} ; 5.9 \mathrm{mmol})$ was placed in a flame-dried flask under nitrogen followed by dry THF $(30 \mathrm{ml})$. Diiodoethane $(1.62 \mathrm{~g}, 5.76 \mathrm{mmol})$ dissolved in dry THF $(5 \mathrm{ml})$ was added slowly at first. After a short induction period, the bulk of the diiodoethane solution was added over 2-5 minutes. A vigorous reaction ensued with the evolution of heat and after 30 minutes a dark blue solution of samarium diiodide was formed. This was treated with a solution of spirolactone 11 (522 $\mathrm{mg} ; 2.373 \mathrm{mmol}$ ) in dry THF (5 ml) at ambient temperature whereupon its color was almost instantaneously discharged to give a brown sludge indicating that the reaction was complete. The brown suspension was poured into saturated sodium bicarbonate solution $(50 \mathrm{ml})$ and layers were partitioned. The aqueous phase was washed with another portion of ether $(25 \mathrm{ml})$ and was then carefully acidified with $2 \mathrm{~N}$ aqueous hydrochloric acid to $\mathrm{pH} 2-3$. Extraction with ethyl acetate $(2 \times 50 \mathrm{ml})$ followed by washing of organics with brine and drying $\left(\mathrm{Na}_{2} \mathrm{SO}_{4}\right)$ afforded acid $12(520 \mathrm{mg} ; 99 \%)$ on concentration as a yellow oil. $v_{\max } 3640-2400,1713 \mathrm{~cm}^{-1} . \delta_{\mathrm{H}}\left(\mathrm{CDCl}_{3}\right)$ $6.10(1 \mathrm{H}$, fine dd; $\mathrm{J}=11.0 \mathrm{~Hz}$ and $\mathrm{J}=1.0 \mathrm{~Hz}) ; 5.85(1 \mathrm{H}, \mathrm{dt} ; \mathrm{J}=11.0 \mathrm{~Hz}$ and $\mathrm{J}=7.0 \mathrm{~Hz}) ; 3.05(2 \mathrm{H}, \mathrm{d}$; $\mathrm{J}=6.0 \mathrm{~Hz}) ; 2.85(2 \mathrm{H}, \mathrm{s}) ; 2.40(2 \mathrm{H}, \mathrm{s}) ; 1.60(3 \mathrm{H}, \mathrm{s}) ; 1.05(6 \mathrm{H}, \mathrm{s}) . \mathrm{m} / \mathrm{e}$ found $222.1256, \mathrm{C}_{13} \mathrm{H}_{18} \mathrm{O}_{3}$ requires 222.1256 .

Preparation of 1,7-dioxo-5,5,8a-trimethyl- $\Delta^{2,3}, \quad \Delta^{4,4 a}$-decalin (13). 2-Chloro- $N$ methylpyridinium iodide (344 mg; $1.351 \mathrm{mmol} ; 1.2 \mathrm{~mol} \mathrm{eq}$ ) and dry TEA (375 $\mu \mathrm{l} ; 2.700 \mathrm{mmol}$; $2.4 \mathrm{~mol} \mathrm{eq})$ were placed in a flame dried 2-neck flask fitted with a reflux condenser. Dry methylene chloride $(4 \mathrm{ml})$ was added and the mixture was brought to reflux under nitrogen. The resulting yellow solution was then treated with a solution of keto acid $12\{250 \mathrm{mg} ; 1.126 \mathrm{mmol}$; $1.0 \mathrm{~mol} \mathrm{eq}\}$ in dry methylene chloride $(3 \mathrm{ml})$ slowly and the mixture was refluxed for a further 4 hours after which TLC showed that the reaction was complete. The reaction mixture was taken up in methylene chloride (30 ml); washed successively with water; sodium bicarbonate solution, 
brine (each $1 \times 15 \mathrm{ml}$ ) and finally dried $\left(\mathrm{Na}_{2} \mathrm{SO}_{4}\right)$. The volatiles were taken off on the rotary evaporator and the concentrate was purified by chromatography (1:1 petrol/ether) to give product 13 as a yellow crystalline solid $(137 \mathrm{mg}, 60 \%)$. It was further purified by recrystallization from 2:1 petrol/ether for analytical purposes: yellow needles, mpt $86-7^{\circ} \mathrm{C} . v_{\max } 1716,1665,1628 \mathrm{~cm}^{-1}$. $\delta_{\mathrm{H}}\left(\mathrm{CDCl}_{3}\right) 7.05\left(1 \mathrm{H}, \mathrm{dd} ; \mathrm{J}=10.0 \mathrm{~Hz}\right.$ and $\left.\mathrm{J}^{\prime}=6.0 \mathrm{~Hz}\right) ; 6.30(1 \mathrm{H}, \mathrm{d}: \mathrm{J}=6.0 \mathrm{~Hz}) ; 5.98(1 \mathrm{H} ; \mathrm{d}, \mathrm{J}=9.5$ $\mathrm{Hz}) ; 2.75(2 \mathrm{H}, \mathrm{q} ; \mathrm{J}=18.0 \mathrm{~Hz}) ; 2.40(2 \mathrm{H}, \mathrm{t}, \mathrm{J}=19.0 \mathrm{~Hz}) ; 1.45(3 \mathrm{H}, \mathrm{s}) ; 1.35(3 \mathrm{H}, \mathrm{s}) ; 1.20(3 \mathrm{H}, \mathrm{s})$. (Found C: 76.9; H: 7.9. Calc. for $\mathrm{C}_{13} \mathrm{H}_{16} \mathrm{O}_{2}: \mathrm{C}, 76.5 ; \mathrm{H}, 7.8$ )

Preparation of 4-[4-hydroxy-2,6,6-trimethylcyclohex-1-enyl]-(z)-3-butenoic acid (14). A solution of keto acid $12(163 \mathrm{mg} ; 0.740 \mathrm{mmol})$ in AR methanol $(5 \mathrm{ml})$ was cooled to $-78^{\circ} \mathrm{C}$ and treated with sodium borohydride $(112 \mathrm{mg}, 2.96 \mathrm{mmol})$ in one batch. The reaction mixture was stirred under nitrogen at $-78^{\circ} \mathrm{C}$ for 3 hours and then it was poured into sodium bicarbonate solution $(10 \mathrm{ml})$. The mixture was carefully acidified with $2 \mathrm{~N}$ hydrochloric acid to $\mathrm{pH} 2$ and then extracted with ethyl acetate $(2 \times 25 \mathrm{ml})$. The combined organics were washed (brine) and dried $\left(\mathrm{Na}_{2} \mathrm{SO}_{4}\right)$. Evaporation of solvent afforded the title compound 14 as a yellow oil (158 mg; $\left.96 \%\right)$. $v_{\max } 3220 ; 3640-2400 ; 1713 \mathrm{~cm}^{-1} . \delta_{\mathrm{H}}\left(\mathrm{CDCl}_{3}\right) 6.05(1 \mathrm{H}, \mathrm{bd} ; \mathrm{J}=10.5 \mathrm{~Hz}) ; 5.75(1 \mathrm{H}, \mathrm{dt} ; \mathrm{J}=11.0 \mathrm{~Hz}$ and $\mathrm{J}=7.0 \mathrm{~Hz}) ; 4.05(1 \mathrm{H}, \mathrm{m}) ; 2.96(2 \mathrm{H}, \mathrm{d} ; \mathrm{J}=7.0 \mathrm{~Hz}) ; 2.20\left(2 \mathrm{H} ; \mathrm{dq} ; \mathrm{J}=15.0 \mathrm{~Hz}\right.$ and $\left.\mathrm{J}{ }^{\prime}=5.0 \mathrm{~Hz}\right)$; $1.65(2 \mathrm{H}) . \mathrm{m} / \mathrm{e} \mathrm{M}^{+}$found $224.1415, \mathrm{C}_{13} \mathrm{H}_{20} \mathrm{O}_{3}$ requires 224.1412

Preparation of acetoxy-5,5,8a-trimethyl-1-oxo- $\left(\Delta^{2,3}, \Delta^{4,4 a}\right)$-decalin (15). A solution of hydroxy acid $14(119 \mathrm{mg} ; 0.531 \mathrm{mmol})$ in dry methylene chloride $(4 \mathrm{ml})$ was treated with pyridine $(2 \mathrm{ml})$ followed by acetic anhydride $(1.5 \mathrm{ml})$ and DMAP (a few crystals). The solution turned brownish at first and after 3 hours yellow. When the reaction was complete, the mixture was taken up in methylene chloride $(30 \mathrm{ml})$ and washed successively with water $(1 \times 10 \mathrm{ml})$; aqueous sodium bicarbonate solution $(1 \times 10 \mathrm{ml}), 2 \mathrm{~N}$ hydrochloride acid $(2 \times 10 \mathrm{ml})$ and finally brine $(1 \times 10 \mathrm{ml})$. The organics were dried $\left(\mathrm{Na}_{2} \mathrm{SO}_{4}\right)$ and concentrated under reduced pressure. The concentrate was purified by chromatography (1:1 petrol/ether) to afford product as a yellow oil $(95 \mathrm{mg} ; 72 \%)$ as a mixture of disastereoisomers. $v_{\max } 1736 ; 1665 ; 1628 \mathrm{~cm}^{-1} . \delta_{\mathrm{H}} 15 \mathrm{a}\left(\mathrm{CDCl}_{3}\right)$ $7.00\left(1 \mathrm{H} ; \mathrm{dd} ; \mathrm{J}=9.5 \mathrm{~Hz}\right.$ and $\left.\mathrm{J}^{\prime}=6.5 \mathrm{~Hz}\right) ; 6.22(1 \mathrm{H}, \mathrm{d}, \mathrm{J}=6.5 \mathrm{~Hz}) ; 5.89(1 \mathrm{H}, \mathrm{d} ; \mathrm{J}=9.5 \mathrm{~Hz}) ; 5.13(1 \mathrm{H}$, m); $2.21(1 \mathrm{H}, \mathrm{dd}, \mathrm{J}=14.0 \mathrm{~Hz}$ and $\mathrm{J}=5.0 \mathrm{~Hz}) ; 2.10(3 \mathrm{H}, \mathrm{s}) ; 1.95(2 \mathrm{H}, \mathrm{m}) ; 1.69(1 \mathrm{H}, \mathrm{dd} ; \mathrm{J}=14.0 \mathrm{~Hz}$ and $\mathrm{J}=5.0 \mathrm{~Hz}), 1.51(3 \mathrm{H}, \mathrm{s}) ; 1.37(3 \mathrm{H}, \mathrm{s}) ; 1.22(3 \mathrm{H}, \mathrm{s})$. GC: $9.11 \mathrm{~min}$ retention time. (Found $\mathrm{C}$ : 72.7; H: 8.4. Calc. for $\left.\mathrm{C}_{15} \mathrm{H}_{20} \mathrm{O}_{3}: \mathrm{C}, 72.6 ; \mathrm{H}, 8.1\right)$

\section{Thermolysis of bicycles 15}

The bicycle $15(29.0 \mathrm{mg})$ was refluxed in o-dichlorobenzene for 10 hours under nitrogen. Then the solvent was taken off on an oil-pump and the residue was purified by chromatography (1:1 petrol/ether) to afford product as a yellow oil $(21 \mathrm{mg} ; 71 \%) . \delta_{\mathrm{H}} \mathbf{1 5 b}\left(\mathrm{CDCl}_{3}\right) 6.97(1 \mathrm{H}$, dd, $\mathrm{J}=10.0 \mathrm{~Hz}$ and $\mathrm{J}=6.0 \mathrm{~Hz}) ; 6.17(1 \mathrm{H}, \mathrm{d} ; \mathrm{J}=6.0 \mathrm{~Hz}) ; 5.92(1 \mathrm{H} ; \mathrm{d} ; \mathrm{J}=10.0 \mathrm{~Hz}) ; 5.30(1 \mathrm{H}, \mathrm{tt} ; \mathrm{J}=11.0$ $\mathrm{Hz}$ and $\mathrm{j}=4.0 \mathrm{~Hz}) ; 2.42(1 \mathrm{H} ; \mathrm{dt} ; \mathrm{J}=12.0 \mathrm{~Hz}$ and $\mathrm{J}=4.0 \mathrm{~Hz}) ; 2.02(3 \mathrm{H}, \mathrm{s}) ; 1.95(2 \mathrm{H}, \mathrm{m}) ; 1.86(1 \mathrm{H}$, $\mathrm{dt} ; \mathrm{J}=12.0$ and $\mathrm{J} \sim 3.0 \mathrm{~Hz}) ; 1.45(3 \mathrm{H}, \mathrm{s}) ; 1.40(3 \mathrm{H}, \mathrm{s}) ; 1.22(3 \mathrm{H}, \mathrm{s})$. GC: 8.93 min retention time. 
Preparation of 7-methanesulfonyloxy-5,5,8a-trimethyl-1-oxo-( $\left.\Delta^{2,3}, \quad \Delta^{4,4 a}\right)$-decalin (16). Hydroxy acid 14 (89 mg; $0.397 \mathrm{mmol})$ was dissolved in dry methylene chloride (4 ml) and the solution was cooled to $0^{\circ} \mathrm{C}$. Triethylamine $(0.65 \mathrm{ml}, 4.8 \mathrm{mmol}$; excess $)$ was added followed by methanesulphonyl chloride ( $92 \mu \mathrm{l} ; 1.192 \mathrm{mmol} ; 3.0 \mathrm{eq})$. The solution was stirred under nitrogen at $0^{\circ} \mathrm{C}$ and slowly allowed to warm up to room temperature over 3 hours. Then the reaction mixture was taken up in methylene chloride $(30 \mathrm{ml})$ and washed with sodium bicarbonate solution $(1 \times 10 \mathrm{ml})$, concentrated on the rotary evaporator. The residue was purified by chromatography $\left(\mathrm{SiO}_{2} ; 2: 1 \mathrm{Et}_{2} \mathrm{O} / \mathrm{Pet}\right)$ to afford the product 16 as a yellow oil $(57.0 \mathrm{mg} ; 50 \%)$. $v_{\max } 1661,1625 \mathrm{~cm}^{-1} . \delta_{\mathrm{H}}\left(\mathrm{CDCl}_{3}\right) 6.95(1 \mathrm{H}, \mathrm{dd} ; \mathrm{J} \sim 9.0 \mathrm{~Hz}$ and $\mathrm{J} \sim 6.0 \mathrm{~Hz}) ; 6.15(1 \mathrm{H}, \mathrm{d} ; \mathrm{J} \sim 6.0$ $\mathrm{Hz}) ; 5.80(1 \mathrm{H}, \mathrm{d} ; \mathrm{J} \sim 9.0 \mathrm{~Hz}) ; 5.00(1 \mathrm{H}, \mathrm{m}) ; 3.00(3 \mathrm{H}, \mathrm{s}) ; 2.40-1.40(4 \mathrm{H}, 6 \mathrm{~m}) ; 1.50(3 \mathrm{H}, \mathrm{s}) ; 1.40$ $(3 \mathrm{H}, \mathrm{d}) ; 1.20(3 \mathrm{H}, \mathrm{s}) . \mathrm{m} / \mathrm{e} 288\left(\mathrm{M}^{+}\right) ; 188\left(\mathrm{M}^{+}-\mathrm{MeSO}_{3} \mathrm{H}\right) ; 173\left(\mathrm{M}^{+}-\mathrm{MeSO}_{3} \mathrm{H}-\mathrm{Me}\right) ; 145(\mathrm{BP})$.

\section{Acknowledgements}

The author wishes to thank the University of Manchester for financial support and the late Professor James K. Sutherland for his advice during the course of this work. Thanks are also due to Professor D. L. J. Clive, University of Alberta (Canada) for his helpful suggestions during the preparation of the manuscript.

\section{References}

1. Barron, C. A.; Khan, N.; Sutherland, J. K. J. Chem. Soc., Chem. Comm. 1987, 1728.

2. Khodabocus, A; Shing, T. K. M.; Sutherland, J. K.; Williams, J. G. J. Chem. Soc., Chem. Comm. 1989, 783.

3. Larsen, L; Sutherland, J. K. J. Chem. Soc., Chem. Comm. 1989, 784.

4. (a) See ref 2. (b) For a related example see Khodabocus, A. ARKIVOC 2000, (i), 854.

5. Marx, J. N.; Sondheimer, F. Tetrahedron Suppl. 1968, 1.

6. Molander, G. A.; Hahn, G. J. Org. Chem. 1986, 51, 1135.

7. Quinkert, G.; Englert, H.; Cech, F.; Stegk, A.; Haupt, E.; Leibfritz, D.; Rehm, D. Ber. 1979, 112, 310 . 